\title{
Calculation Quest
}

\author{
And the winner is...
}

\section{Andrew Crumey}

Professor Beatrice Ghosian, flanked by two male colleagues, was about to announce the winner of Calculation Quest 2055.

"Ladies and gentlemen," she began, "as you know, we invited the global public to participate in a unique computational experiment. Simply by watching our series on their Personal Entertainment Consoles, viewers have donated a portion of processor time to be used on a massive calculation chosen by our panel of experts.

"Initially, 50 calculations were proposed by our team of cultural commentators, style gurus and celebrity mathematicians. Over the weeks, that list was reduced through a rigorous process of peer review, group challenges and luck, until just three were left.

"Number one: calculation of the complete field equation of non-perturbative M-theory. Number two: to find a solution to world poverty and inequality. Number three: to create a perfect work of art. I now hand you over to Zane Budolsky, professor of comparative studies at Pennine University, Alston."

Budolsky, seated beside her, wore a thirties-style jumpsuit and had the air of an old-fashioned television philosopher. "Let me elucidate the finalists' charms and negativities," he said. "First, the equation of Mtheory. This has been an outstanding problem of theoretical physics for more than half a century. And during all that time, physicists have assured us it will be solved next week. So let's wait until next week: they can do it for themselves.

"Number two. Solution to world poverty. We really liked this. But as my colleague Professor 'Rude Ron' Ronson has said: if we can't work out the answer in our own heads, maybe we don't deserve a solution found by other means. And that leaves the third option..."

He was cut off by a wave of Beatrice Ghosian's jewelled hand. "But the suspense isn't over. In fact, it's only beginning. The panel also had to take account of the people's choice, and I can announce that in this category, after a tough contest, the winner was. ..to work out where flies go to in winter."

Warm applause from the audience then another flick of Beatrice Ghosian's long-nailed fingers, commanding silence.

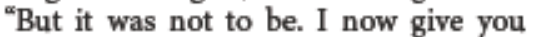
Starkling Bland, emeritus professor of colour at Ocean University 3, St Helena, who will explain why."

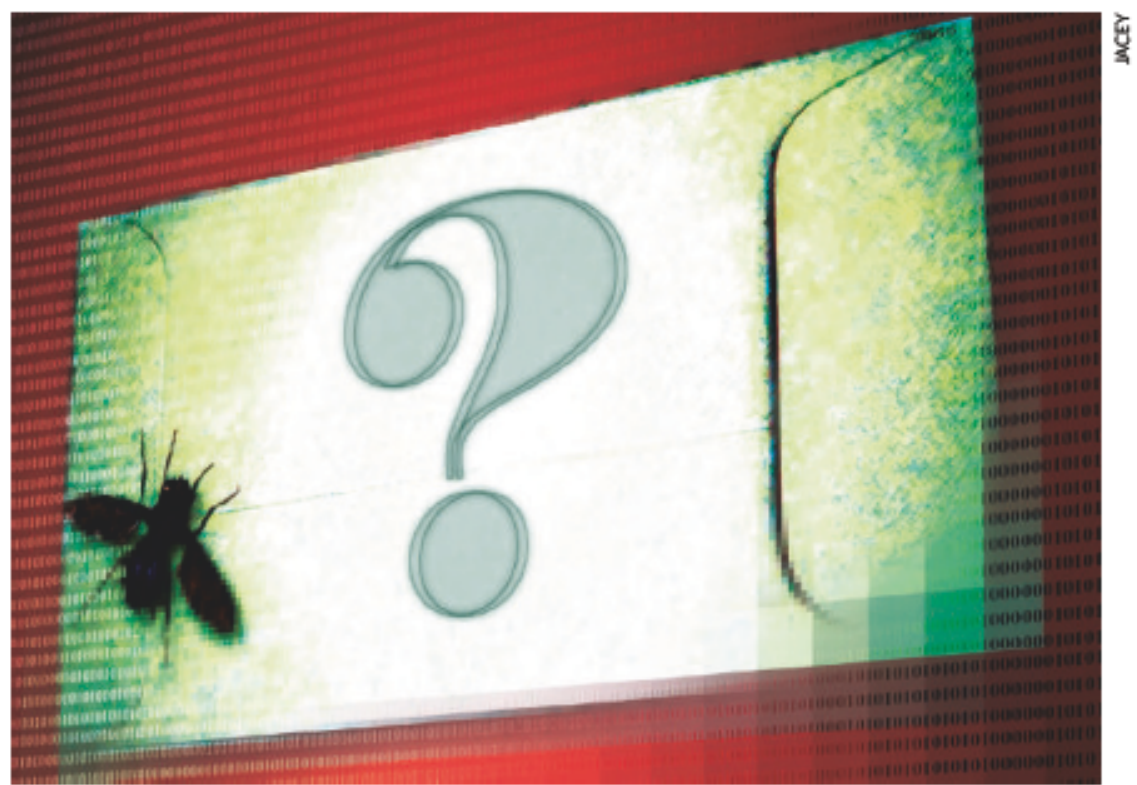

Slumped in his chair, Bland seemed soundly asleep, possibly working off the effects of a long night of narcotaine smoothies. Given a prod, he roused himself and cast his bleary eyes across the multitude.

"The calculation, Stark," Professor Ghosian prompted. "Perfect work of art."

${ }^{\alpha}$ Total," he said, suddenly igniting " ${ }^{\text {"W }}$ What an exceptional field it's been in this year's Calculation Quest. Particularly as this is the only year the show has run. And I hear they've axed the next series. So this is it, folks: the one and only. And that's why we really craved the work-of-art thing, number three. Loved it. Great package. The bidding team was so good. That housewife from Frankfurt. And the little guy with the thing in his ear. Personalities. That's what it's all about. You want a really great calculation it's all about selling yourself.

${ }^{\alpha}$ But which work of art? A symphony for wind chimes? An animated movie? A make-over? Art's a big sausage. Here's what we did: we tossed a coin. And we decided on literature."

From the audience, a low but distinctly perceptible moan. Professor Ghosian's features registered the shift:Calculation Quest was in sudden danger of going all wrong. With the second series cancelled, Ghosian's academic career was already on the rocks. Now it was her pension that was at stake.

"Yes! ${ }^{\prime}$ she cried with forced animation, silencing Starkling Bland at a stroke. "Literature. You may call it outmoded, but that's nothow we see things at Calculation Quest. Throughout the past seven days, the Personal Entertainment Consoles of 3.1 billion viewers have been at work. We fed in every literary masterpiece in history; every criti$\mathrm{cal}$ analysis and commentary; every review. We left processing power to do what no human has ever achieved, racing through a hundred lifetimes of development and experience, gleaned through the literature of ages. And now we have it - yes, here in this room. The computation ended today at $5: 32$ universal time. In front of me I have the perfect work of literature."

It was inside a box whose lid Professor Ghosian now opened. What came out was not a book, but an envelope.

${ }^{\alpha}$ Micro!" laughed Starkling Bland. "We got ourselves a haiku!"

Beatrice Ghosian was unruffled. "It has long been known that poetry is the highest form of literature. And I don't suppose the field equation of M-theory would have filled a novel either." She tore open the envelope, pulled out a white card and stared at it in silence.

"Go on, then," said Zane Budolsky. "Let's hear it!"

All the literature in history had gone into this. And that, Beatrice Ghosian realized, was the problem. Somehow, all those computers had failed to add up, but instead had only averaged — like the show she'd devised and now saw sinking along with her hopes. There were two short words printed on the card. They summed up her feelings exactly.

Andrew Crumey did a PhD in theoretical physics at Imperial College London, and is currently literary editor of Scotland an Sunday. His latest novel is Mobius Dick (Picador). 